\title{
PENGARUH KOMPENSASI TERHADAP PRESTASI KERJA KARYAWAN PADA CV. SEDULUR PALEMBANG
}

\author{
Oktariansyah *)
}

\begin{abstract}
ABSTRAK
Penelitian ini bertujuan untuk mengetahui dan menganalisis pengaruh kompensasi terhadap prestasi kerja karyawan pada CV. Sedulur Palembang. Rumusan masalah dalam penelitian ini adalah adakah pengaruh kompensasi terhadap prestasi kerja karyawan pada CV. Sedulur Palembang?

Populasi dalam penelitian ini adalah seluruh karyawan yang bekerja di CV. Sedulur Palembang berjumlah 90 orang karyawan. sedangkan sampel yang diambil sebanyak 48 orang. Teknik yang digunakan pada uji teknik instrumen data yaitu uji validitas dan reliabilitas kemudian Regresi linier sederhana analisis korelasi dan uji t serta metode yang digunakan yaitu analisis kualitatif dan kuantitatif.

Hasil output regresi linier sederhana dengan menggunakan spss 17 for windows yaitu $Y=22,295+$ $0,265 \times$ dengan analisis korelasi didapat nilai $R=0,385$, ini berarti terdapat pengaruh kompensasi terhadap prestasi kerja karyawan pada CV. Sedulur Palembang. dan menolak hipotesis nol karena nilai thitung lebih besar dari pada t-tabel yaitu 3,644 > 1,662 semakin tinggi kompensasi yang diberikan maka prestasi kerja yang dihasilkan meningkat.
\end{abstract}

\section{Kata Kunci : Kompensasi, Prestasi Kerja.}

\section{A. Latar Belakang}

Prestasi kerja merupaan hal penting bagi kelangsungan sebuah perusahaan, karena prestasi kerja merupakan suatu hasil yang dicapai seseorang dalam melaksanakan tugas - tugas yang dibebankan, atas kecakapan, pengalaman, dan kesungguhan dalam mencapai prestasi yang tinggi.

Perusahaan harus mampu menciptakan kondisi dan situasi yang dapat memberikan semangat kerja bagi karyawan, karena hanya karyawan yang memiliki keahlian yang tinggi dan komunikasi yang baik akan mempunyai prestasi yang baik pula. Berbagai cara seseorang manajer melaksanakan tugasnya agar tujuan perusahaan tercapai antara lain dengan pemberian kompensasi yang wajar.

Perusahaan mengharapkan agar kompensasi yang diberikan dapat meningkatkan prestasi kerja karyawan. Jika pimpinan perusahaan kurang memperhatikan para karyawan dalam

\footnotetext{
*) Dosen Tetap Fakultas Ekonomi UPGRI Palembang
}

melaksanakan tugasnya, dikhawatirkan prestasi kerja karyawan menurun.

Pemberian kompensasi sangatlah penting pengaruhnya, tidak hanya meningkatkan prestasi kerja karyawan namun juga untuk meningkatkan kesejahteraan karyawan dan tentunya sangat berguna bagi pihak perusahaan, dengan demikian akan tercipta hubungan harmonis antara pimpinan perusahaan dengan karyawan.

Apabila kompensasi yang ada di perusahaan dapat di jalankan dengan baik maka perusahaan akan dapat mempertahankan karyawan sebaliknya, jika kompensasi tidak berjalan dengan baik maka karyawan akan bekerja secara tidak maksimal.

Pemberian kompensasi karyawan harus mempunyai dasar yang rasional. Namun demikian, faktor emosional dan perikemanusiaan tidak boleh diabaikan. Kompensasi dikatakan penting bagi karyawan karena besar kecilnya kompensasi merupakan ukuran nilai terhadap kerja karyawan itu sendiri. 
Besar kecilnya kompensasi dapat mempengaruhi prestasi kerja, motivasi, kepuasan kerja karyawan.

Apabila pemberian kompensasi diberikan secara tepat, maka para karyawan akan memperoleh kepuasan kerja dan termotivasi untuk mencapai tujuan organisasi. Dengan demikian dapat disadari bahwa suatu kompensasi dapat meningkat atau menurunkan prestasi kerja, kepuasan kerja, maupun motivasi karyawan.

CV. Sedulur Palembang merupakan perusahaan yang bergerak dibidang Contractor, supplier dan developer pembangunan perumahan yang ada dikota palembang.

Jadi, permasalahan di CV. Sedulur Palembang untuk meningkatkan prestasi kerja karyawan dengan cara memberikan kompensasi sehingga perusahaan tersebut dapat berjalan dengan baik. Kondisi inilah yang menarik perhatian peneliti untuk melakukan penelitian

\section{B. Rumusan Masalah}

Berdasarkan latar belakang permasalahan yang ada, maka dapat dirumuskan yaitu adakah pengaruh kompensasi terhadap prestasi kerja karyawan pada CV. Sedulur Palembang?

\section{Metode Penelitian}

Metode dalam penelitian ini adalah metode penelitian asosiatif yang bertujuan untuk mengetahui pengaruh dua variabel atau lebih. Sugiono (2010:55).

\section{Populasi dan Sampel}

1) Populasi

Menurut Sugiyono (2008: 115) Populasi adalah wilayah generalisasi yang terdiri atas Objek/subyek yang mempunyai kualitas dan karakteristik tertentu yang ditetapkan oleh peneliti untuk dipelajari dan ditarik kesimpulannya. Populasi dalam penelitian ini adalah seluruh karyawan yang bekerja di CV. Sedulur Palembang berjumlah 90 orang karyawan.

Tabel 1

Jumlah karyawan CV. Sedulur Palembang

\begin{tabular}{|c|l|c|}
\hline No & \multicolumn{1}{|c|}{ Jenis Jabatan } & Jumlah \\
\hline 1 & Direktur & 1 \\
\hline 2 & Kepala Divisi & 3 \\
\hline 3 & $\begin{array}{l}\text { Manajer Sumber Daya } \\
\text { Manusia }\end{array}$ & 1 \\
\hline 4 & Manajer Teknik dan & 1 \\
\hline 5 & $\begin{array}{l}\text { Manajer Adm, } \\
\text { Perlengkapan }\end{array}$ & 1 \\
\hline 6 & Manajer Pemasaran & 1 \\
\hline 7 & Manajer Keuangan & 1 \\
\hline 8 & Manajer Produksi & 4 \\
\hline 9 & Staff unit Pemasaran & 3 \\
\hline 10 & Staff unit Teknik & 2 \\
\hline 11 & Staff unit Keuangan & 4 \\
\hline 12 & Staff unit Administrasi & 2 \\
\hline 13 & Staff unit Produksi & 1 \\
\hline 14 & Staff unit Perlengkapan & 63 \\
\hline 15 & $\begin{array}{l}\text { Staff unit Sumber Daya } \\
\text { Manusia }\end{array}$ & 90 \\
\hline 16 & Pekerjaan harian \\
\hline & \multicolumn{2}{|c|}{ Jumlah } \\
\hline
\end{tabular}

Sumber : CV. Sedulur Palembang, 2017

\section{2) Sampel}

Menurut Sugiyono (2008: 116) Sampel adalah bagian dari jumlah dan karakteristik yang dimiliki populasi tersebut. Adapun jumlah sampel tersebut diperoleh dari perhitungan yang dikemukakan oleh Slovin (Umar, 2008) sebagai berikut :

$$
n=\frac{N}{1+N e^{2}}
$$

Dimana:

$n=$ Ukuran sampel

$\mathrm{N}=$ Ukuran populasi

$\mathrm{e}=$ Persen kelonggaran ketidaktelitian karena kesalahan 
pengambilan sampel yang masih dapat ditolerir atau diinginkan, sebesar $10 \%$.

$$
\begin{aligned}
& n=\frac{N}{1+N e^{2}} \\
& n=\frac{90}{1+(90)(0,1)^{2}} \\
& n=\frac{90}{1+0.9}=48
\end{aligned}
$$

Berdasarkan uraian diatas, maka penulis mengambil sampel sebanyak 48 orang.

\section{E. Teknik Pengumpulan Data}

Menurut Umar (2011: 49-51), ada beberapa teknik pengumpulan data yang dapat dilakukan dalam penelitian ini adalah :

a. Angket ( kuesioner )

Adalah suatu pengumpulkan data dengan cara memberikan atau menyebarkan daftar pertanyaan/pernyataan kepada responden dengan harapan akan memberikan respon atas daftar pertanyaan tersebut.

Teknik pengumpulan yang digunakan dalam penelitian ini adalah kuesioner.

b. Observasi

Adalah pengumpulan data yang dilakukan melalui pengamatan dari si peneliti baik secara langsung maupun tidak langsung terhadap objek penelitiannya.

\section{F. Teknik Analisis Data}

Analisis data yang digunakan dalam penelitian ini adalah Kualitatif dan Kuantitatif. Secara kualitatif digunakan dengan skala likert dengan pilihan jawaban responden sebagai berikut :
Sangat setuju
Setuju
$=\mathrm{SS}$
Ragu-ragu
$=\mathrm{S}$
Tidak setuju
$=R$
Sangat tidak setuju
$=$ TS
= STS

Kemudian dikuantitatifkan sebagai berikut:

$\begin{array}{ll}\text { Sangat Setuju } & =5 \\ \text { Setuju } & =4 \\ \text { Ragu - ragu } & =3 \\ \text { Tidak Setuju } & =2 \\ \text { Sangat Tidak Setuju } & =1\end{array}$

G. Hasil Penelitian

1) Uji validitas

a. Kompensasi (variabel $x$ )

Kompensasi diukur dengan delapan butir pernyataan. Uji coba instrumen telah dilakukan terhadap 48 orang responden yang dipilih secara acak. Perhitugan uji validitas dilakukan dengan Korelasi Product Moment dengan bantuan program SPSS for Windows versi 17. Hasil uji validitas dari 8 butir pernyataan pada variabel kompensasi

\section{Tabel 2}

\section{Uji Validitas untuk Variabel Kompensai}

\begin{tabular}{|c|c|c|c|c|}
\hline Item & T-hitung & $r$-tabel & Kriteria & Keterangan \\
\hline 1 & 0,630 & 0,285 & $r_{\text {hitung }}>r_{\text {tabel }}$ & Valid \\
\hline 2 & 0,588 & 0,285 & $r_{\text {hitung }}>r_{\text {tabel }}$ & Valid \\
\hline 3 & 0,631 & 0,285 & $r$ hitung $>r_{\text {tabel }}$ & Valid \\
\hline 4 & 0,632 & 0,285 & $r_{\text {hitung }}>r_{\text {tabel }}$ & Valid \\
\hline 5 & 0,616 & 0,285 & $r_{\text {hitung }}>r_{\text {tabel }}$ & Valid \\
\hline 6 & 0,630 & 0,285 & $r_{\text {hitung }}>r_{\text {tabel }}$ & Valid \\
\hline 7 & 0,664 & 0,285 & $r_{\text {hitung }}>r_{\text {tabel }}$ & Valid \\
\hline 8 & 0,543 & 0,285 & $r_{\text {hitung }}>r_{\text {tabel }}$ & Valid \\
\hline
\end{tabular}

Sumber : Hasil pengolahan data, 2017 
Berdasarkan tabel menunjukan semua butir pernyataan pada variabel kompensasi menunjukan $r_{\text {hitung }}>r_{\text {tabel }}$ berarti seluruh butir dapat dikatakan valid. Hal ini berarti bahwa semua butir yang dijadikan sebagai indikator terhadap variabel kompensasi telah sah untuk dijadikan sebagai alat ukur dalam penelitian ini. b. Uji Validitas Prestasi Kerja (Y)

Prestasi Kerja diukur dengan 8 butir pertanyaan. Uji coba instrumen telah dilakukan terhadap 48 orang responden yang dipilih secara acak. Perhitugan uji validitas dilakukan dengan Korelasi Product Moment dengan bantuan program SPSS for Windows versi 17. Hasil uji validitas dari 8 butir pernyataan pada variabel Prestasi kerja terlihat seperti pada tabel .

\section{Tabel 3}

\section{Uji Validitas untuk Prestasi Kerja}

\begin{tabular}{|c|c|c|c|c|}
\hline Item & T-hitung & $\mathrm{r}$-tabel & Kriteria & Keterangan \\
\hline 1 & 0,528 & 0,285 & $\mathrm{r}$ hitung $>\mathrm{r}_{\text {tabel }}$ & Valid \\
\hline 2 & 0,464 & 0,285 & $\mathrm{r}_{\text {hitung }}>\mathrm{r}_{\text {tabel }}$ & Valid \\
\hline 3 & 0,727 & 0,285 & $\mathrm{r}$ hitung $>\mathrm{r}_{\text {tabel }}$ & Valid \\
\hline 4 & 0,532 & 0,285 & $\mathrm{r}_{\text {hitung }}>\mathrm{r}_{\text {tabel }}$ & Valid \\
\hline 5 & 0,585 & 0,285 & $\mathrm{r}_{\text {hitung }}>\mathrm{r}_{\text {tabel }}$ & Valid \\
\hline 6 & 0,828 & 0,285 & $\mathrm{r}_{\text {hitung }}>\mathrm{r}_{\text {tabel }}$ & Valid \\
\hline 7 & 0,632 & 0,285 & $\mathrm{r}_{\text {hitung }}>\mathrm{r}_{\text {tabel }}$ & Valid \\
\hline 8 & 0,563 & 0,285 & $\mathrm{r}_{\text {hitung }}>\mathrm{r}_{\text {tabel }}$ & Valid \\
\hline
\end{tabular}

Sumber : Hasil pengolahan data, 2017

Berdasarkan tabel diatas menunjukan semua butir pernyataan pada variabel Prestasi Kerja menunjukan $r_{\text {hitung }}>r_{\text {tabel }}$ berarti seluruh butir dapat dikatakan valid. Hal ini berarti bahwa semua butir yang dijadikan sebagai indikator terhadap variabel prestasi kerja telah sah untuk dijadikan sebagai alat ukur dalam penelitian ini.

\section{2) Uji Reliabilitas Instrumen}

\section{a. Uji Reliabilitas Kompensasi (X)}

Hasil perhitungan nilai reliabilitas Cronbach Alpha untuk variabel Kompensasi dengan bantuan program SPSS for Windows versi 17 dapat dilihat pada tabel berikut ini.
Tabel 4

Uji Reliabilitas untuk Variabel Kompensasi

Reliability Statistics

\begin{tabular}{|l|l|}
\hline Cronbach's Alpha & N of Items \\
\hline .766 & 8 \\
\hline
\end{tabular}

Berdasarkan tabel menunjukan bahwa nilai Cronbach Alpha sebesar 0.766 . Karena nilai reliabilitas lebih besar dari 0,6 maka dari 8 butir pernyataan yang dijadikan sebagai indikator pada variabel Kompensasi sudah reliabel.

\section{b. Uji Reliabilitas Prestasi Kerja}

Hasil perhitungan nilai reliabilitas Cronbach Alpha untuk variabel Prestasi Kerja dengan bantuan program SPSS for Windows versi 17 dapat dilihat pada tabel berikut ini. 
Tabel 5

Uji Reliabilitas untuk Variabel

Prestasi Kerja

Reliability Statistics

\begin{tabular}{|l|l|}
\hline Cronbach's Alpha & N of Items \\
\hline .743 & 8 \\
\hline
\end{tabular}

Berdasarkan tabel menunjukan bahwa nilai Cronbach Alpha sebesar
0.743. Karena nilai reliabilitas lebih besar dari 0,6 maka dari 8 butir pernyataan yang dijadikan sebagai indikator pada variabel Prestasi Kerja sudah reliabel.

3) Analisis data

a) Regresi Linier Sederhana Regresi linier sederhana menggunakan SPSS for Windows versi 17 dapat dilihat pada tabel berikut ini :

Tabel 6

Hasil Uji Regresi Linier Sederhana

Coefficients $^{a}$

\begin{tabular}{|c|c|c|c|c|c|}
\hline \multirow[b]{2}{*}{ Model } & \multicolumn{2}{|c|}{ Unstandardized Coefficients } & $\begin{array}{l}\text { Standardized } \\
\text { Coefficients }\end{array}$ & & \\
\hline & B & Std. Error & Beta & $\mathrm{t}$ & Sig. \\
\hline (Constant) & 22.295 & 2.399 & & 9.292 & .000 \\
\hline $\mathrm{x}$ & 265 & .073 & 362 & 3.644 & .000 \\
\hline
\end{tabular}

a. Dependent Variable: $Y$

Persamaan sebagai berikut :

$\mathrm{Y}=\mathrm{a}+\mathrm{b}_{\mathrm{x}}$

$Y=22.295+0,265 X$

Konstanta sebesar 22.295 artinya kompensasi nilainya adalah 0 maka prestasi kerja karyawan sebesar 22.295 Sedangkan koefisien regresi variabel kompensasi sebesar 0,265 artinya jika kompensasi mengalami kenaikan 1 maka prestasi kerja karyawan mengalami peningkatan 0,265 koefisien bernilai positif artinya ada pengaruh positif antara kompensasi dengan prestasi kerja karyawan. Semakin tinggi kompensasi yang diberikan maka akan meningkat prestasi kerja karyawan.

\section{b) Koefisien korelasi sederhana}

\section{Hasil Uji korelasi Sederhana Model Summary}

\begin{tabular}{|l|r|r|r|r|}
\hline Model & $\mathrm{R}$ & R Square & Adjusted R Square & $\begin{array}{c}\text { Std. Error of the } \\
\text { Estimate }\end{array}$ \\
\hline 1 & $.362^{2}$ & .131 & .121 & 2.370 \\
\hline
\end{tabular}

a. Predictors: (Constant), $\mathrm{X}$

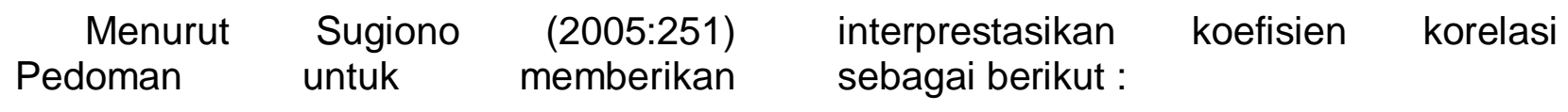


Tabel 8

Koefisien Korelasi

\begin{tabular}{|c|c|}
\hline Interval koefisien & Tingkat hubungan \\
\hline $0,00-0,199$ & Sangat rendah \\
$0,20-0,399$ & Rendah \\
$0,40-0,599$ & Sedang \\
$0,60-0,799$ & Kuat \\
$0,80-0,1000$ & Sangat kuat \\
\hline
\end{tabular}

Koefisien korelasi sederhana (r) adalah 0,362 maka dapat disimpulkan bahwa terjadi hubungan yang rendah antara kompensasi terhadap prestasi kerja. koefisien determinasi ( $r 2$ ) sebesar $0,131(13,1 \%)$ maka dapat disimpulkan kompensasi memberi sumbangan terhadap prestasi kerja sebesar 13,1\% selebihnya sebesar 86,9 \% dipengaruhi oleh variabel lain yang tidak diteliti oleh peneliti.

\section{4) Uji hipotesis}

\section{Tabel 9}

\section{Hasil Uji Linier Sederhana}

Coefficients $^{\mathbf{a}}$

\begin{tabular}{|l|r|r|r|r|r|}
\hline \multirow{2}{*}{ Model } & \multicolumn{2}{|c|}{$\begin{array}{c}\text { Unstandardized } \\
\text { Coefficients }\end{array}$} & \multicolumn{1}{c|}{$\begin{array}{c}\text { Standardized } \\
\text { Coefficients }\end{array}$} & & \\
\cline { 2 - 4 } & \multicolumn{1}{|c|}{$\mathrm{B}$} & Std. Error & \multicolumn{1}{|c|}{ Beta } & \multicolumn{1}{c|}{ T } & \multicolumn{1}{c|}{ Sig. } \\
\hline 1 (Constant) & 22.295 & 2.399 & & 9.292 & .000 \\
$\mathrm{X}$ & .265 & .073 & .362 & 3.644 & .000 \\
\hline
\end{tabular}

a. Dependent Variable: $Y$

Setelah diperoleh hasil perhitungan koefisien korelasi antara kompensasi dan prestasi kerja maka dilakukan uji hipotesis dengan langkah-langkah pengujian berikut :

a) Menentukan Hipotesis

Ho : tidak ada pengaruh antara kompensasi dan prestasi kerja

$\mathrm{Ha}$ : ada pengaruh antara kompensasi dan prestasi kerja

b) Menentukan signifikan

Tingkat signifikan menggunakan 0,05 . Signifikan 0,05 adalah ukuran standar yang sering digunakan dalam penelitian

c) Menentukan t-hitung

Berdasarkan output yang diperoleh thitung sebesar 3.644

d) Menentukan t-tabel

Tabel distribusi $\mathrm{t}$ dicari pada $=5 \%$ (uji 2 sisi) dengan derajat kebebasan (df) $n-k-1$ atau $90-1-1=88$. (n) adalah jumlah kasus dan $\mathrm{k}$ adalah jumlah variabel (independen) dengan pengujian 2 sisi (signifikan $=0,05$ ) hasil diperoleh untuk t-tabel sebesar 1,662

e) Kriteria pengujian

Ho : artinya Tidak adanya pengaruh kompensasi terhadap prestasi kerja karyawan pada CV. Sedulur Palembang

$\mathrm{Ha}$ : artinya Adanya pengaruh kompensasi terhadap peningkatan prestasi kerja pada CV. Sedulur Palembang

f) Apabila t-hitung > t-tabel maka Ho ditolak

Artinya ada hubungan yang disignifikan antara kompensasi dengan prestasi kerja karyawan

g) Apabila t-hitung < t-tabel maka Ho diterima 
Artinya tidak ada hubungan yang signifikan antara kompensasi dengan prestasi kerja karyawan

h) Membandingkan t-hitung dengan ttabel

Nilai t-hitung > t-tabel ( $3.644>$ 1,662) maka Ho ditolak Ha diterima artinya ada pengaruh secara signifikan kompensasi dengan prestasi kerja. Jadi dapat disimpulkan bahwa kompensasi berpengaruh terhadap prestasi kerja karyawan pada CV. Sedulur Palembang.

\section{H. Pembahasan.}

Berdasarkan hasil analisis regresi linier sederhana dapat diketahui bahwa terdapat pengaruh antara variabel kompensasi $(\mathrm{x})$ dan prestasi kerja $(\mathrm{y})$ pada CV. Sedulur Palembang, hal ini dapat ditunjukan dari persamaan regresi linier sederhana $Y=22,295+0,265 X$. Nilai koefisien regresi variabel kompensasi $(x)$ sebesar 0,265 artinya jika pengaruh kompensasi mengalami kenaikan 1, maka prestasi kerja (y) akan mengalami peningkatan sebesar 0,265. Koefisien bernilai positif artinya terdapat pengaruh positif antara kompensasi dengan prestasi kerja karyawan, semakin tinggi nilai kompensasi yang diberikan oleh kantor maka akan meningkat prestasi kerja.

Hasil koefisien korelasi sederhana $(r)$ adalah 0,362 . Koefisien determinasi ( $r 2$ ) sebesar $0,131 \quad(13,1 \%) \quad$ ini mengambarkan bahwa kompensasi mempengaruhi prestasi kerja karyawan pada CV. Sedulur Palembang sebesar $13,1 \%$ sedangkan sisanya $86,9 \%$ dipengaruhi oleh faktor-faktor lain yang tidak diteliti dalam penelitian ini antara kompensasi dengan prestasi kerja karyawan adalah rendah.
Untuk uji hipotesis nilai t-hitung $>\mathrm{t}$ tabel, $(3,644>1,662)$. Jadi Ho ditolak $\mathrm{Ha}$ diterima, maka dapat disimpulkan bahwa ada pengaruh secara positif antara kompensasi dengan prestasi kerja karyawa pada CV. Sedulur Palembang. Dari sini dapat diketahui bahwa kompensasi yang diberikan pimpinan kepada karyawan memberi semangat bagi mereka bekerja. Kita mengetahui semangat diperlukan dalam semua aktivitas atau pekerjaan.

\section{Kesimpulan}

1. Diperoleh persamaan $Y=22,295+$ 0,265X artinya jika kompensasi mengalami kenaikan 1 maka prestasi kerja karyawan (Y) mengalami peningkatan 0,265

2. Koefisien determinasi ( $r 2$ ) sebesar $0,131 \quad(13,1 \%)$ ini mengambarkan bahwa kompensasi mempengaruhi prestasi kerja karyawan pada CV. Sedulur Palembang sebesar $13,1 \%$ sedangkan sisanya $86,9 \%$ dipengaruhi oleh faktor-faktor lain yang tidak diteliti dalam penelitian ini antara kompensasi dengan prestasi kerja karyawan adalah rendah.

3. Hasil pengujian hipotesis nilai $t-$ hitung > t-tabel $(3.644>1,662)$, maka Ho ditolak dan Ha diterima. Berarti bahwa ada pengaruh yang signifkan antara Kompensasi (X) terhadap Prestasi kerja Karyawan (Y).

\section{J. Saran}

1. Pihak CV. Sedulur Palembang seharusnya memperhatikan masalah kompensasi yang tentu saja akan berpengaruh pada prestasi kerja karyawan.

2. Perusahaaan sebaiknya memberikan kompensasi yang sesuai dan tepat 
waktu, sehingga dapat memberikan prestasi kerja bagi karyawannya.

3. Perusahaan harus mampu menciptakan kondisi dan situasi yang kooperatif sehingga dapat menunjang prestasi kerja karyawannya.

\section{DAFTAR PUSTAKA}

Handoko T.hani .2009.Manajemen. Edisi 2, BPFE,Yogyakarta.

Malayu SP Hasibuan. 2009.Manajement Sumber Daya Manusia, edisi Revisi, Bumi Aksara, Jakarta.

Marlina.2009.Pengaruh Kompensasi Terhadap Prestasi Kerja Karyawan Pada PT Usaha Jaya Palembang,FE-UPGRI,Skripsi tidak dipublikasikan.

Manullang. 2008. Dasar-dasar Manajemen. Gajah mada.
Sugiyono.2005. Statistika Untuk Penelitian. Alfabeta, Bandung .2008. Metode Penelitian Bisnis. Alfabeta,Bandung. 2009. Metode Penelitian Bisnis. Alfabeta,Bandung 2010. Metode Penelitian Bisnis.Alfabeta,Bandung

.2011. Metodologi Penelitian Kuantitatif, Kualitatif dan $R \& D$. Bandung: Alfabeta.

Soekidjo Notoatmojo. 2009. Pengembangan Sumber Daya Manusia, Cetakan Kartika, Penerbit PT Rineka Cipta, Jakarta.

Umar, Husein. 2011. Metode Penelitian Untuk Skripsi dan Tesis. Penerbit PT. Raja Grafindo Persada, Jakarta. 